\title{
THE SHAMAN AS THE ZOOMORPHIC HUMAN
}

\section{$\underline{\text { Triinu Ojamaa }}$}

In this paper the shaman's transformations into an animal or a bird by means of casbing spells and studied with a great importance attached to the question by which means are these transformations made visible and audible. The inspiration for the research is got from the Nganasan foretelling spell in $1990(* 1)$ and that is why the work is that nganasan-centred. The comparative material of the subject both of the nothern and the southern regions of Siberia, and of some other regions of the world offers a great deal of parallels. This indicates that the technical skills of the ritual are widespread.

The shaman's transformation into the animal or the bird is connected with his helping spirit and his guardian spirit. The Buryat, for example, name the shaman's guardian spirit 'khubilgan', which could be translated 'metamorphosis' (compare with the verb 'khubilkhu' - 'to change oneself", 'to take another shape' (Eliade 1974)). The presence of the shaman's spirits is considered to be the most essential requirement, as the spirits are that who give the shaman all the information and practical aid on his ecstatic journeys. Majority of the shaman's spirits, especially in Siberian shamanism, have taken the shape of the animal or the bird (Hultkranz 1978). The Nganasan name their shaman's spirits d'a-mad'i (Kortt \& Simchenko 1985: d'amáda 'animal' or 'zoomorphic', ie. 'having a throat'), despite of whether the spirit is zoomorphic or antropomorphic. Gracheva (Gracheva 1983) considers the term to be the opposite of the term 'séjmid'a, which is translated by Kortt and Simchenko as "having the eyes", and commented on as a synonym both of a human being and of an animal.

Usually wild game, such as a bear, an elk, a seal, a wolf, a hare, a deer etc. appear as the helping spirits. Among the domestic animals a horse is known as the shaman's spirit for the Yakut, and for the Ostyak and the Vogul who use the horse to go to the Heaven (Karjalainen 1918). Among the ornitomorphic helping spirits a goose and a diver are the most prevalent as being the good divers, as well as a swan, an owl, a crow, and an eagle are widespread. For the Lapps fish may appear as the helping spirits, and for the Tungus people the helping spirits may appear in the shape of snakes.

Usually the shaman's helping spirit makes an animal or a bird without any special characteristic features or originality. The contray examples are given by the Netsilik Eskimo's comparatively extravagant spirits, where the zoomorphic spirits have it's originality. For example, a very big grampus (Arlu); a black earless dog (Kunnararjuq); a giant bear that especially loves human flesh (Naroluk), and some others (Balicki 1970).

There are three different ways of zoomorphic and ornitomorphic transformation in Siberian shamanism. They are: objective transformations, soundic transformations, and expressive transformations.

The whole shaman's equipment beginning from the costume to finish with the smallest details of it symbolizes a certain animalor a bird. The Nganasan shaman's costume symbolizes an elk. It is sewn of elk hide with a metal figure of a hartshorn on it's back. The Nganasan instepless boots remind of elk feet. Majority of the pendants fastened to the costume represent some shaman's spirits. Gracheva describes the two bear figures on the Nganasan shaman's costume as symbolizing a shebear and a he-bear. According to the shaman's explanations, he can team the bears to a sledge, and they take him wherever he wants, and "with that quickly that nothing could be seen but the wind is 
whistling in the ears". In addition to the bear figures, there are six goose's head figures, and three bird tails. The goose's head figures are needed to move through the air to the upper world. The bird tails help the shaman to dive. The shaman has to dive when healing people, as the Nganasan consider water to be the location of sick spirits. They say that the sick people's spirits are held there. When the shaman finds out the wanted spirit, he seats it on the bird tail, and fastens it to the tail with a chain for it didn't get lost on the way back, and returns it to the sick person.

Whereas the shaman's costume as the whole symbolizes the elk, the fringed sleeves of the costume symbolize the bird wings. Gracheva describes a case that the shaman clasp the patient, and spreads the leather fringe, sewn to his sleeves, over the patient. According to the shaman's comments, he defends the sick person from sick spirits like a bird protects its pinfeathered youngs (Gracheva 1978).

In Siberian peoples' shamanism a drum symbolizes a draught animal, mainly an elk. Zhornitskaya describes a ride on the drum when the shaman bestrides the drum and bumps himself as whwn riding the elk. Such practice is spread among Ostyak-Samoyedic shamans and Evenk shamans. Although the Nganasan are not familiar with the practice of riding on elk, still the drum is the symbol of the elk for them. According to Dolgih's data the Nganasan shaman Kherepte(?) imitated the elk by means of the drum scraping the ground with the drumbuttons $(* 2)$ like the elk scrapes the ground with its forelegs (Dolgikh 1978) ( $(\underline{3})$.

The zoomorphic transformations described above are expressive rather than objective. By expressive transformation we mean imitating of the movements of animals or birds. These transformations could be rhytmless movements, such as the turn of the body, the wave of the hand etc.,pantomimes, or dances. Actually, one can't draw the line between the pantomime and the dance. In some researchers the difference is made on the ground of eirher it is a mere imitating of someone, or some meaningless rhytmical movements are added. The Eskimo's pantomimes imitating the shaman's zoomorphic spirits are distinguished from their ceremonial dances, for example (Driver 1970).

In most cases the imitating of animals is classified as a dance. Zhornitskaya differentiates two subdivisions of a ritual dance, such as imitating ritual dances and ecstatic ritual dances. In case of the imitating ritual dance, there is the transformation into zoomorphic spirits into which the shaman changes himself on his journey. The ecstatic ritual dance is to help the shaman to reach ecstasy. Both these subdivisions are improvisatory, and consist of the widely spread imitating movements without any certain succession. They are considered to be dances because the movements are always carried out with a certain rhytm (Zhornitskaya 1992).

The imitating of behaviour and uttering sounds of animals and birds is a widespread and extremely old practice, as the information of it appears in the travel books written several centuries ago. The earliest data about the Samoyed, the Ostyak, and the Vogul peoples' imitating practices date back to the 18th century (Romenskaya 1986). In the diary of his travels to Siberia in the 1840s Middendorff gives a detailed description of the samoyed roundelay in which the bear movements are imitated, and it is accompanied by grunting coughing, which is obviously the uttering sound of the bear (Middendorff 1987). Thus the practice shouldn't be looked at as a part of shamanism only, but it is also a part of social entertainment. Both in case of the practice being a social entertainment, and in case of the practice being a shamanistic ritual, the imitating of the movements of animals or birds is accompanied by the imitating of the uttering sounds of animals or birds.

The imitating of the uttering sounds of animals or birds can be either natural or symbolic. In case of natural imitations some one uttering sound, such as a whistle, a cry, a howl, etc. is imitated as alike to the real uttering sound as possible. The natural imitations have of practical importance above all. 
They are used to decoy the animals, whereas the human voice timbre is completely concealed. The uttering sounds of birds can be imitated by means of different whistling techniques, and by means of decoy whistle. In case of the sounding imitations produced by the human voice the usual vocalphonetic intonation is not used. The uttering sound of birds are imitated by means of a falsetto. The uttering sounds of animals are produced by means of a nose-throat articulation based on one respiratory cycle, which enables to provide hoarses, grunts, roars, etc (Sheikin 1983; Sheikin 1984; Kim \& Sheikin 1986).

The symbolicimitations of uttering sounds are based on the real uttering sounds of animals or birds, whereas the intonation is transformed by man. The result of it is a note pattern which expresses the main characteristic features of the source signal. Less complicated imitations, such as the cuckoo's calling etc., are closer to the source sound, and both the rhytm and the pitches of the signal are quite original. More complicated imitations are man's creation rather than the uttering sounds of birds. To confirm the above-mentioned there is the song of the great northern diver (sample 1) which differs from the source signal in its substantially slower movement, abd also in its varied melody arrangement (compare with the sample 8 where there is the pattern of the uttering sounds of the diver in the shaman's ritual). The using of the falsetto and the syllabled text imitating "the bird's language" emphasize that this concerns the uttering sounds of birds.

The sounding imitations by which the shaman expresses his transformations into the animal or the bird, are substantially closer to the source sounds than the song of the great nothern diver mentioned above.

Next, a brief survey of Djulsymjaku Kosterkin's foretelling spell is given. The three travel episodes of the spell contain a great deal of expressive and sounding imitations. The purpose of the spell was to find out how many years would the shaman's patient live. Majority of the spell was carried out singing. The practice lasted 3 hours and 50 minutes, and only 40 minutes of it were occupied by talk.

All the melodies performed during the spell belong to the shaman's helping spirits and guardian spirits. These melodies could be considered to be the personal melodies, as they are named after the spirits' names. In the present time the Nganasan don't associate the genesis of songs with the spirits. The songs are considered to be created by the shamans themselves. The melodies created by the shamans don't have any feature characteristic of that particular genre as compared to the nganasan melodies in general. Although the majority of these melodies belong to the zoomorphic spirits not one of them personates a melodic characteristic of a particular animal or bird.

The same melody may have different functions during the practise. In the exposition of the show the melodies act as call signs, i.e. the singing of these melodies is expected to fetch their owners. According to the nganasan shamanistic ritual, the call signs are syllabilized in a nonsensical way. Some peoples, such as the Ostyak, have the instrumental call signs which are performed on string instruments named either "nars-juh", or "panan-juh" Alekseyenko, 1988).

Having taken the advices of the fetched spirits the shaman starts his hypothetical journey. The travel episodes are those where the shaman transforms himself into a bird or an animal depending on where he happens to go.

Djulsymjaku's 1st travel episode is accompanied by the song in the melody of the song of na-rka 'ne-me (the song of the she-bear), which works as the travel song tara-rsa ba-'le (compare with the verb taru-d'a 'to start moving').

The nganasan shamans cast spells in the sitting position. Standing up is the sign that the journey is going to begin. In the 1 st travel episode the shaman imitates the elk. The expressive transformation 
starts with the walk on the spot, that is accompanied by the bows (i.e. the shaman in the shape of the elk tries to find the right path), and by the nods of the head. Next, he turns a semicircular to the sunwise (i.e. like the Heaven revolves), and imitates the grunts of the elk (sample 2). During the journey the shaman's assistant holds the chain fastened to the back of the shaman's costume (as if people held the chain for nobody didn't miss or get lost. The shaman is the chief elk, that is followed by all the others) $(\underline{*})$. Next, the shaman imitates the flight of the swan and the uttering sounds of the swan (sample 3). The whole episode is accompanied by the melody of ka-d'a ko-'pta (i.e. the thundermaid's melody) which doesn't belong to any particular ornitomorphic or teriomorphic helping spirit. Djulsymjaku explains that this melody is chosen because "the clowds are like the birds, as they also travel".

After the travel episode the shaman sits down and starts telling the stories about what he has seen on his journey, and at the same time the spirits repose who helped the shaman on his journey.

In the 2nd travel episode the shaman imitates the bear. The finding of the right path is carried out in the sitting position. The shaman casts an investigating glance to the right and to the left, next he shrugs his shoulders and shakes his head. Then he rises to his feet and moves slowly to the sunwise. His movement is accompanied by the recitative a-nt'ina ma-nt'ina å-ku ai. These are the meaningless words, or the shaman's words as the comment says. However, the nganasan bear dance is accompanied by these words. The recitative syllabled text alternates with the imitations of the grunts of the bear (the ritual episode: sample 4; the dance: sample 5). After the bear dance the shaman starts imitating the elk. The walk on the spot becomes more energetic, and finally becomes the run on the spot. The crooked arms move from front to back like when increasing the spead. These movements are accompanied by the imitating of the coughs of the elk (waf-waf). The walk becomes slower and unrhytmical. The shaman in the shape of the elk bows and imitates sniffing.

In the following episode the shaman says that he walked along the crooked path, and that he needs flyers, i.e. the birds as the helping spirits who could lead the way when he happens to lose it. Before starting for his 3rd journey the shaman makes it sure whether he is on the right path or not. It takes place by means of a song which goes like this:

We lived with the wild elks

There was fish enough

The clothes were made of elk hide

I am no more the master of the elks.

The spirits answer by the mouth of the shaman's assistant:

You are correct

You are on the right path

Go forward.

Next there is the most long-lasting and the most emotional journey which starts with the finding of the right path like the previous episodes did. It goes like this: the shaman bows and straightens his back, and looks around searching with his his arm concealing the eyes. Then he beckons forward with his arm whereas his look is irresolute; next he retreats; then he picks his steps forward again. His movements are unrhytmical, and the practice resembles a pantomime. Then he stops short and hits the ornament worn round his neck (it is the figure of the helping spirit) with the drumstick for he had been shown the way. Then he gives the drum to the assistant and goes down on one knee, rocking his body to and fro; then he streches his arnes out with the palms upward, and starts beckoning. 
The practice is accompanied by the song with the following content:

The path that we rode along before is covered with snow. The path was visible as the elk teams rode along it. Now I can no more find the path as I can see very little. Now there are the roads for tractors and snowmobiles. Now I am in the closed house(*5). If I were in the tent, perhaps it would be easier to find my way. Here I can see nothing. I can but nose my way out. The shamanistic path is completely invisible, as the place is unknown. Some spirits tell me "to be careful; not to stand up! not to fall into the evil spirits' hands; not to hurry; when you hurry, it will drain you. You would walk slower for you could bring your children up to maturity. The evil spirits look out of the Earth. If you hurry, you can't see them, but they have to be driven away.

When singing the shaman rocks himself unrhytmically. His gestures are hesitant and his glances back are anxious.

Next the shaman sings that he is a bear (to the melody of the song 'na rka ne me, sample 6) and he imitates the roaring of the bear (to drive away the evil spirits).

Then the shaman in the shape of the bear becomes the shaman in the shape of the goose, and its flight is expressed by the imitating of flaps of the wings, by the sudden lifts of the heels, and by making circles by the hips. The expressive imitations are accompanied by the sounding imitations of the goose. These practices are accompanied by the tinkle of the ornaments fastened to the shaman's costume (sample 7). Suddenly the goose changes its manner of flying. The shaman moves his stiff arms up and down, and in doing this he makes sudden jolts with his wrists. Then the goose becomes the bear again, and the roars of the bear and the shamanistic words are uttered alternately. The journey is continued along the road.

While the movements of the birds and the animals are imitated only in travel episodes, the sounding imitations appear in some other kinds of episodes, too. For example, Djulsymjaku imitates the uttering sounds of a great northern diver (sample 8) in the song that comes after the call signs. The song says that all the spirits of importance are present, and the foretelling may begin. The song is to the melody of the song of the great northern diver (the song of o-tare, sample 6 ).

For some peoples the sounding imitations act as the call signs. In case of the Orotsh funeral feasts of the bear, the killed bear is brought up to the house where the majority of the feast is carried out. Inside the house the roaring of the bear is imitated, meaning that the bear is expected to come in (Sheikin 1986). The Nganasan don't use the sounding imitations as call signs. After the show the shaman has to gather all the helping spirits together, and "put them to sleep". Djulsymjaku comments on it: "The Heaven is foursquare, like a sheet of paper is. These four corners are like the four quarters of the horizon. The spirits will sleep under the sheet of paper. You must not wake them up until the next spell."

The spirits are called together by means of the following calls:

Dis

ko-u ko-u ko-u ko-u

In most cases the calls like that appear in the spell, as it is seen in sample 9, which is a fragment of Tubjaku Kosterkin's spell in 1989(*7). Whwn the shaman's assistant gives the call signs to the spirits, the rest of the people participating in the ritual have to support him by calls, for the spirits reacted to them quicker. Such practice is spread among the samoyed peoples living in the northern areas. 
Eis
E
E
o-uok o-uk o-uk
Ges
F
u-ok u-ok u-ok u-ok

These calls come from the "vocabulary" of the reindeer breeders. They use the calls like that or similar to that to call the herd of reindeer together. When the reindeers cross the river the Nganasan support them by the calls "he-hei-heh!" (sample 10). In case of a spell the shaman uses these calls to make his hypothetic draught animal move quicker (sample 11). Here it follows that the shaman communicates with his zoomorphic helping spirits like people communicate with the real animals.

The calls used by the reindeer breeders are rather melodic, especially the call "he-hei". The Nganasan consider the calls to be "the music created by Man to make the reindeers cross the river quickier, and to prevent them from cold in the cold water."

The movements by which the shaman expresses his transformations are widespread among Siberian peoples, i.e. the different peoples imitate the same objects in the same way. For example, flying of a bird is imitated by moving the arms extended sideways up and down; and the ride on a draught animal is imitated by bumping himself as when riding a real animal.

There are regional differences in sounding imitations but the practice itself is spread all over Siberia. The Ostyak are the exception of it, as they have the songs that represent some animal or bird, but they lack the practice of sounding imitations because they consider it making fools of the birds or the animals. However, the Vogul are familiar with the practice of sounding imitations. Rombandejeva describes the episode of the funeral feast of the bear where the spirit in the shape of the bear named Jalius ojka appears and he makes a circle to the sunwise, and spits every now and then like the bear. Rombandejeva also mentions a human being imitating a sea gull by means of moving his arms extended sideways up and down, like the sea gull flaps its wings, and utters the following sounds: "tjar-tjar-tjar" (Rombandejeva 1993).

Eliade considers the sounding imitations as a code that the shaman uses to communicate with the spirits. In several Indian tribes both in North America and South America it is compulsory for the shamans to acquire the imitating skills during the initiation period. According to Eliade's data the Lapps, the Chukchi, the Yakut, and the Tungus practiced the code. He objects against the Sienkewicz-Gudkova's statement when saying that the Ostyak also practiced the code (Eliade 1974). It is self-evident that the code is not used beyond the rituals. The taboos forbid the Orotsh to provide some naturalistic sounding imitations (Kim \& Sheikin 1986). It is a practical taboo rather than theoretical as the Siberian peoples consider the sounding imitations to be the genre of music that precedes to the song, and they are practiced not only by the shamans but also by other people.

The genres of epic also contain the sounding imitations of animals and birds. It can be exemplified by the fragment of the nganasan song si tabi (i.e. the heroic song) where the singer imitates the uttering sounds of an owl and the flaps of its wings that is marked under the staff. The uttering sounds of birds are imitated in children's plays, too.

On the one hand the sounding imitations can be considered to be entertainment, that get their subject from everyday life. On the other hand in some languages the words "magic" and "song" (especially "bird song") are marked by the same word. In germanic languages the word "magic" is 
marked by the word "galdr" which comes from the verb galan 'to sing ', especially 'to sing a bird song' (Eliade 1974).

In Nganasan epic a mythical hero is able to understand the sounding imitations of animals and birds, and to act in the way the animals or the birds do (to fly, for example). Both in the old heroic songs and in shamanism Man can have animals and be identified with animals simultaneously. The general idea of the shaman's journey is perhaps the imaginary return to the period of time when the men and the animals were the same?

\section{Commentaries}

1. The video signal recording of the ritual is in the collection of the Estonian Literary Museum named after F.R.Kreutzwald.

2. The drumbuttons, or the drumknobs are the parts of the instrument which have an acoustic purpose. They produce an empty space between the drumskin and the frame of the drum which acts as a resonator, as it can be seen in the following figure.

3. In addition to the drum being a draught animal, there are some other objects which can be expressed by means of the drum in Siberian shamanism. For example, it may symbolize a boat, a cloud, etc, but for certain the drum symbolizes the object by means of which one can move forward. 4. In the literature in the field of etnography the chain has somewhat different purpose. It is fastened to the pole of the tent for the shaman didn't fall into the fire.

5. Djulsymjaku Kosterkin performed the spell in the sound recording studio of Novosibirsk Conservatoire.

6. xo:tare is a mythical name for the great northern diver (the general name for the diver is nuo na). O:tare is the shaman Demnime's (Djulsymjaku's father) helping spirit which is the antropoornitomorphic spirit, i.e. the bird that, when coming out of the water, takes the shape of the woman. 7. The video signal recording is made in the village named Ust-Avam, and the recording is in the collection of the Estonian Folklore Archives.

\section{References}

Alekseenko, E. 1988. Muzykalnye instrumenty narodov Severa Zapadnoi Sibiri. Materialnaya $i$ dukhovnaya kultura narodov Sibiri. Leningrad.

Balicki, A. 1970. The Netsilik Eskimos. Illinois.

Dolgikh, B. 1978. Nganasan Shaman Drums and Costumes. Shamanism in Siberia. V. Diószegi, M. Hoppál (eds.). Budapest.

Driver, H. E. 1970. Indians of North America. Chicago and London.

Eliade, M. 1974. Shamanism. Archaic Techniqes of Ecstasy. Bollingen Series LXXVI. Princeton. Gracheva, G. 1978. Nganasan Shaman Costume. Shamanism in Siberia. V. Diószegi, M.Hoppál (eds.). Budapest.

Gracheva, G. 1983 Traditsionnoye mirovozreniye okhotnikov Taimyra. Lenigrad. Hultkranz, A 1978. Etiological and Phenomenological Aspects of Shamanism. Shamanism in Siberia. V. Diószegi, M. Hoppál. Budapest.

Karjalainen, K. F. 1918. Jugralaisten uskonto. Suomensuvun uskonnot III. Porvoo.

Kim, N., Sheikin, Y. 1986. Zhanrovoye tipologia muzykalnogo folklora orochei. Muzykalnoye tvorchestvo narodov Sibiri i Dalnego Vostoka. Novosibirsk.

Kortt, Y., Simtschenko, Y. 1985. Wörterverzeichnis der Nganasanischen Sprache. Berlin. 
Middendorff, A. Th. von 1987. Reis Taimõrile. Tallinn.

Rombandeyeva, E. 1993. Istoria naroda mansi (vogulov) i ego dukhovnaya kultura. Surgut. Romenskaya, T. 1986. Ob istochnikakh izuchenia muzykalnoi kultury narodov Sibiri XVIII - pervoi poloviny XIX vekov. Muzykalnoye tvortchestvo narodov Sibiri i Dalnego Vostoka. Novosibirsk. Sienkiewicz-Gudkova, V. 1980. Nekotorye muzykalnye i poeticheskie ossobennosti saamskikh i hantyiskikh pesen o zveryakh i ptits. Rüütel, I. (sost.) Finno- ugorskii muzykalnyi folklor $i$ vzaimosvyazi s sosednimi kulturami. Tallinn.

Sheikin, Y. 1983. Problema zhanra v muzykalnom folklore ude. Avtoreferat. Leningrad. Sheikin, Y. 1984. Intonatsionnyi ideal muzykalnogo folklora ude. Kultura narodov Dalnego Vostoka. Vladivostok.

Zhornitskaya, M. 1978. Yakut Shaman Dances. Shamanism in Siberia. V. Diószegi, M. Hoppál (eds.). Budapest.

Zhornitskaya, M. 1992. Shamanskie plyaski narodov Sibiri. Ranniye formy religii narodov Sibiri. Sankt-Peterburg. 